\title{
O Curso de Geografia Física de Imannuel Kant e a construção metafísica da superfície da Terra.
}

\author{
Antonio Carlos Vitte * \\ Alexandre Domingues Ribas**
}

\section{Resumo.}

O presente artigo argumenta que o curso de geografia física de Imannuel Kant é o produto de uma reflexão filosófica e cosmológica, devido a problemática em se estabelecer a regularidade da natureza que é espacialmente diferenciada e regulada por fundamentos mecânicos e causais. A partir de problemas filosóficos relacionados às teses desenvolvidas na Crítica da Razão Pura, a partir de críticas advindas dos viajantes e naturalista sobre a sua concepção de universalidade do conceito de natureza e sobre a sua concepção de espaço; Kant é obrigado a rever sua posição filosófica, que acontecerá somente a partir de uma profunda revisão dos conceitos de metafísica, matéria, espaço e natureza. O espaço, agora, não mais ideal, passa a ser a categoria estruturante do mundo empírico, onde a geografia é qualificada como a ciência do espaço, a partir de uma reflexão metafísica sobre a natureza e Terra, erguendo assim as bases para uma filosofia da geografia na modernidade.

Palavras-Chave: Filosofia Kantiana; Geografia Física; Metafísica; Espaço; Razão; Natureza.

\section{The Course of Physical Geography Imannuel Kant's metaphysics and the construction of the surface of the Earth.}

\section{Abstract.}

The present article argues that the course of physical geography of Imannuel kant is the product of a philosophical and rise cosmological reflection from the problem in if establish the nature regularity differentiated and regulated by mechanical and causal foundations. Starting from philosophical problems related the thesis developed in the Criticism of the Pure Reason, of the criticisms come upon of naturalists and about its concept universally conception of nature and of space, kant is grateful to review its philosophical position, that only will happen starting from a profound examine of the metaphysics concepts, matter, space and nature. The space, now, not ideal, proceeds being a organize category of the empiric world that is cognoscible, where the geography is qualified as the space science, starting from a metaphysical reflection about nature and the earth rising this way, the bases for a geography philosophy in the modernity.

Keywords: Kantian Philosophy; Physical Geography; Methaphysic; Space; Mind; Earth.

\section{Introdução}

A proposta do presente artigo é contribuir para a construção da história e da epistemologia da ciência geográfica. Para tanto, vamos nos debruçar sobre o curso de geografia física, de Imannuel Kant, que foi lecionado na Universidade de Koingsberg pelo filósofo, de 1756 à 1800 , cabendo a Th. Rink reunir as anotações e publicá-la em 1802, na

*Antonio Carlos Vitte. Departamento de Geografia, Programa de Pós-Graduação em Geografia, Instituto de Geociências, Unicamp, Campinas (SP), Brasil. CP6152, CEP 13083-970. E-mail: vitte@uol.com.br. Pesquisador CNPq.

**Alexandre Domingues Ribas. Doutorando em Geografia, IG-Unicamp, Professor do Departamento de Geografia da Unioeste, Campus de Francisco Beltrão (PR). E-mail: ribasalex4@hotmail.com. 
forma de um manual, com o aval de Kant. Sem fechar a questão, mas chamando-a ao diálogo e ao debate, a nossa tese é que a ciência geográfica, na modernidade, alcança sua validade e ao mesmo tempo fundamenta enquanto discurso estéticocientífico, a própria modernidade, conferindo uma ordem ao espetáculo da natureza em toda a sua multiplicidade e, com isso, outorgando uma cosmovisão aos espaços renovados da Modernidade.

Nesse processo insere-se o curso de geografia física de Imannuel Kant que corrobora a legitimidade da Geografia atribuindo-Ihe como objeto de estudo o espaço, conceito este que autorizaria essa ciência a atingir a variedade e a empiricidade da natureza em sua totalidade e, deste modo, a oferecer uma imagem atualizada do mundo.

Não menosprezando questões de ordem geopolítica envolvidas na constituição da geografia moderna (Moraes, 1981, 1989), na estreita relação entre o saber geográfico e o poder dos Estados Nacionais, a ponto de gerar escolas nacionais de geografia (Claval, 2006), a nossa tese fundamentase no postulado de que o estatuto científico para a Geografia, fundamenta-se antes em uma discussão filosófica, sobre a natureza e a ordem espacial, ou seja, a ciência estruturando-se a partir de preceitos cosmológicos regidos por um re-pensar metafísico. Há uma clara relação dialética entre forma e conteúdo na constituição da ciência geográfica, o que, muito mais do que nos apegarmos ao vocábulo geografia e quando o mesmo foi utilizando em algum título de alguma obra na modernidade, como é o caso da Antropogeografia de Ratzel (Capel, 1982). A construção historiográfica a nosso ver, requer um árduo trabalho na fronteira e um constante diálogo com vários campos científicos, posição existencial perigosa, mas necessária, pois, acreditamos que é dessa dialética que emergirá o espaço dotado de estatuto ontológico que garantirá o recorte temático e espistemológico da ciência geográfica na modernidade.

É por essa razão que acreditamos que há um trabalho geográfico em Alexander von Humboldt (1769-1859), assim como em Varenius (16211650), em Carl Ritter (1779-1859) e em Imannuel Kant (1724-1804), que lecionou regularmente por quarenta anos (1756-1800) o Curso de Geografia Física, concomitante ao de Metafísica (COHENHALIMI, 1999). Cujo interesse a nosso ver, mais do que preocupações com a localização dos fatos e fenômenos na superfície da Terra, foi cosmológica e metafísica, ou seja, a de fundar e constituir empiricamente um sentido e uma cosmovisão de superfície da Terra e da espacialidade da natureza, fato que foi desenvolvido por Alexander von Humboldt em suas obras.

Assim sendo, é na conjuntura de reformulação metafísica da idéia de substância e, por esta forma, dos juízos de matéria, de espaço, de natureza e de causalidade, que a identidade epistemológica da ciência geográfica demarca sua compleição na modernidade. Desse modo, a geografia cumpre, precisamente, o papel de outorgar uma propriedade científica à justificação (e legitimação) do empírico da experiência moderna, especialmente quando se põe a empiricizar a redescoberta (moderna) do mundo, via reinvenção metafísica da superfície da Terra. Nesse sentido, o saber geográfico científico funda-se, sobretudo, como produtor e difusor de uma cosmovisão moderna (GOMES, 2000).

\section{De Newton à Kant: a constituição da Geografia Física}

Crepúsculo da primeira metade do século XVIII. A Europa savante curvava-se ante o alentado e irreversível triunfo da ciência newtoniana ${ }^{1}$. A mentalidade intelectual da época, em sua maior parte, rendia-se a Newton e à sua proposta de uma nova grade conceitual a ser aplicada à natureza e à Ciência ela mesma (ABRANTES, 1989).

Outono de 1740; dia de São Miguel. Após oito anos no Friedrichs-Gymnasium, Kant ingressa na Universidade de Königsberg, donde estudou matemática, ciências da natureza, teologia, filosofia e letras clássicas latinas (HÖFFE, 2005). Entre seus docentes, Martin Knutzen (1713-1751), com quem teve aulas de lógica e metafísica, prontamente auferiu sua admiração (DE QUINCEY, 1989). O professor Martin Knutzen, um incontido partidário de Newton, incumbiu-se de apresentar a nova filosofia natural ao jovem Kant e este, arrebatado 
de entusiasmo, não hesitou em estabelecê-la como um protótipo universal ao ato de fazer ciência e, também, como uma metodologia inconcussa ao exame da natureza.

$\mathrm{Na}$ verdade, Kant, como um partícipe do Iluminismo europeu, mostrou-se, desde sua juventude, fortemente fascinado com o avanço experimentado pelas ciências naturais modernas. E a física de Newton - avaliada, por ele, como a amostra cumeada desse avanço - vinha resolver as carências da física cartesiana (em parte já acusadas por Leibniz). Não por acaso, em 1746, Kant redigiu uma obra ${ }^{2}$ consagrada à questão da avaliação das forças vivas; um problema sugerido, exatamente, por Leibniz contra os cartesianos.

Assim, a atmosfera intelectual que rodeava a mente do jovem Kant era demasiado complexa, pois recaia sobre ela, ao mesmo tempo, a altivez da filosofia natural de Newton (em cotejo com o mecanicismo cartesiano) e as exegeses, atribuídas a ela, pela metafísica alemã, notadamente por Leibniz (1646-1717) e, também, por Wolff (16791754). A ciência newtoniana e a metafísica alemã. Os artesãos do progresso das ciências naturais modernas (Galileu, Descartes, Newton, etc.) de um lado; e, de outro, Leibniz, Wolff e suas inquietações metafísicas. Esse é o ambiente que incita Kant a fundar aquela que é, talvez, a coluna capital de seu projeto filosófico: elevar a metafísica à condição de ciência. Por essa razão, a filosofia kantiana começa como metafísica, ou, como teoria da filosofia.

E essa busca por uma metafísica científica é que dirige Kant a introduzir, na discussão filosófica, a crítica transcendental da razão, sendo esta última entendida como o adequado método para se desvelar os elementos independentes da experiência e, assim, permitir, apesar de nossa finitude, a universalidade e a necessidade do saber, do agir moral, etc. (HÖFFE, 2005). É essa revolução no pensar que, para Kant, colocaria a filosofia sobre um fundamento definitivamente seguro (HÖFFE, 2005).

Todavia, Kant acreditava que a "[...] questão de uma filosofia científica autônoma não pode ser resolvida de modo abstrato, mas somente por uma investigação de problemas objetivos centrais" (HÖFFE, 2005, p. XX). E foi, justamente, ansiando erigir uma filosofia científica a partir do exame de problemas substanciais que ele consagrou-se, entre outros assuntos, a formular um modelo de inteligibilidade da natureza e um sistema cosmológico. Destarte, ao inquirir metafisicamente nosso mundo natural, Kant pretendia, maiormente, forçar a filosofia a vigiar com cuidado (e a interrogar) sua própria possibilidade.

Produzir uma metafísica da natureza, para Kant, significava proporcionar um conhecimento da natureza a partir de princípios a priori ${ }^{3}$. Seguramente, é essa ambição pela universalidade e pela necessidade que justifica a larga aceitação, por Kant, da filosofia natural de Newton, notadamente na primeira fase do seu transcurso intelectual ${ }^{4}$.

\section{Cosmologia, natureza e espaço na primeira idade da filosofia transcendental kantiana}

Nessa primeira fase da concepção cosmológica de natureza em Kant, não há, decerto, uma uniformidade discursiva e, muito menos, a adesão incondicional a uma única referência teórica (científica ou filosófica). No período que vai de 1747 (com seus Pensamentos sobre a verdadeira avaliação das forças vivas) até 1781 (com sua sublime Crítica da Razão Pura), Kant põe-se em diálogo com uma abundância expressiva de pensadores. Assim, julgar essa fase primeira da filosofia kantiana como um objeto histórico homogêneo seria um desacerto irredimível.

Todavia, mesmo sabedores do caráter arbitrativo dessa apreciação, decidimos versar essa primeira idade como distinguida, fundamentalmente, pela afirmação, por parte de Kant - em detrimento de outras possibilidades interpretativas, como a metafísica de Leibniz e de Wolff, ou, mesmo a física cartesiana - da ciência newtoniana como um modelo de inteligibilidade da natureza, num sentido físico, metafísico e cosmológico.

O primeiro escrito de Kant, redigido em 1746, quando ele tinha 22 anos de idade, já faz intenso uso de idéias newtonianas, pactuando-as ora com o mecanicismo cartesiano, ora com o dinamismo leibniziano. Amparado, notadamente, no famoso texto conclusivo da Opticks, Kant ostenta, com consistência, as teses newtonianas 
da "[...] simplicidade da natureza, da inércia da matéria e da reintegração das forças que continuamente se perdem no universo" (CASINI, 1995 , p. 127).

Seja dito de passagem, nesse texto de 1746, procurando acarear - perante o problema do cálculo da força - os leibnizianos e os cartesianos, Kant manifesta uma iniciativa preocupação com a possibilidade de uma razão humana universal. $E$ a ausência de uma concordância, entre os mais respeitáveis cientistas da época, sobre o cálculo da força, colocava em perigo, justamente, a asserção dessa universalidade. Atentamos, de tal modo, que Kant demonstra, já em seu alvorecer intelectual, um límpido (e proeminente) compromisso com o significado metafísico da ciência física da natureza.

Quando de seu escrito primogênito, a física de Newton já se apresentava, a Kant, mesmo que embrionariamente, como uma metodologia a ser aplicada, paradigmaticamente, ao estudo da natureza e ao próprio ato de fazer ciência. Não obstante, Kant mostra-se ainda hesitante, pois ele caminha sobre a superfície segura desse arquétipo de inteligibilidade da natureza (amplamente glorificado como sendo um irrefragável gerador de um conhecimento universal e necessário) carregando em seus ombros o peso das aflições metafísicas de Leibniz, especialmente ante a filosofia mecânica (newtoniana e cartesiana).

Desse modo, a metafísica de Leibniz cumpre uma influência dilatada na aurora da vida intelectual de Kant. E Leibniz, entre outras coisas, acusava a filosofia natural (e a física) newtoniana de ser desprovida de um fundamento metafísico. Ele, igualmente, não condescendia com o exagerado mecanicismo saído da imagem arquitetural do mundo físico aclamada por Newton. $E$ não é custoso apreender essa sua atitude, já que, do ponto de vista cosmológico, Leibniz consagrouse, corajosamente, a conjugar pressuposições aparentemente incompatibilizáveis: o ideal de uma explicação matemática do mundo; a universalidade das leis da mecânica; e uma concepção teleológica da natureza. E vai ser, exatamente, a metafísica que fornecerá, em Leibniz, o amálgama para se estabelecer essa ligadura entre o racionalismo matemático, o mecanicismo e o finalismo.

Mas, como harmonizar o racionalismo matemático (caracteristicamente cartesiano) e o mecanicismo de Newton com uma concepção teleológica que coloca em ordem a natureza e o universo mediante um finalismo preestabelecido? Leibniz pretende resolver essa questão resguardando-se numa concepção dinâmica da matéria (em oposição a uma concepção geométrica e mecânica dos corpos). Para ele, os seres não seriam máquinas que se movem, mas forças vivas; os corpos mostrar-se-iam, assim, não como extensão, mas como forças e a matéria, por sua vez, seria essencialmente atividade. Tais assertivas conduzem Leibniz a afiançar "[...] que o universo é composto por unidades de força, as mônadas, noção fundamental de sua metafísica" (CHAUÍ, 1983, p. 99). E seriam justamente as mônadas que garantiriam a unidade sistemática do mundo, isto é, os cosmos.

E, como as mônadas, para Leibniz, só podem começar por criação ${ }^{5}$, o universo (que é um agregado de mônadas) e sua harmonia cósmica seriam dependentes de razões metafísicas e não apenas da extensão matemática e mecânica (ROSS, 2001). Por isso, se fazia cogente "[...] tornar toda explicação mecânica dependente em última análise de uma versão metafísica [...]" (ROSS, 2001, p. 95). Em Leibniz, portanto, o universo é concebido como um organismo pleno, cujas partes se conciliam numa harmonia natural e preestabelecida, já que "[...] os atos de cada mônada foram antecipadamente regulados de modo a estarem adequados aos atos de todas as outras [...]" (CHAUÍ, 1983, p. 100).

Se a conexão, que faz do agregado um conjunto sistemático, depende de um Ser único de necessidade metafísica, Deus é, assim, a causa eficiente e a causa final do universo. Como, na matéria, só há excertos de partes ao infinito, a unidade cosmológica residiria somente em Deus. Assim, o universo leibniziano é uma "máquina divina", ideada pelo "autor da natureza". Uma máquina perfeita, onde "[...] não há nada de inculto, estéril ou morto [...]" (LEIBNIZ, 1983, p. 112). Por essa razão, resumir a constituição, a ordenação e a unidade do universo à matéria não passaria, para Leibniz, de um disparate.

Incitado por essa altercação em torno da metafísica do mundo (envolvendo leibnizianos, 
newtonianos e cartesianos) e, também, pela ocorrência, em 1755, do terremoto de Lisboa (que despertou a contenda a respeito da ordem e da finalidade da natureza), Kant decide se debruçar, definitivamente, sobre questões de ordem cosmológica. Eis, então, que em março de 1755, é publicada, anonimamente, sua História Geral da Natureza e Teoria do Céu, uma obra vastamente newtoniana e muito pouco leibniziana ${ }^{6}$.

Nesse escrito, Kant - apoiado em Descartes e no mecanicismo de Newton - se propõe a descobrir "[...] o sistema [...] que reúne os grandes membros da criação em toda a extensão da infinidade" (1984, p. 65, tradução nossa) e a fazer derivar "[...] das leis mecânicas, a formação dos próprios corpos celestes e a origem de seus movimentos do primeiro estado da natureza $[\ldots]$ " (p. 65, tradução nossa). E a universalidade da lei da gravitação newtoniana é que garantiria um sistema de mundo unificado "[...] a partir de uma conexão das substâncias coexistentes" (CLAVIER, 1997, p. 49, tradução nossa).

Portanto, já em 1755, o modelo newtoniano começa a ganhar ênfase nos estudos de Kant sobre a cosmologia da natureza. Foi ainda nesse ano que Kant obteve o seu desejado título de licenciado junto à Faculdade de Filosofia de Königsberg e, desde então, passou a estar habilitado a abrir um curso livre (BOROWSKI, 1993). Um ano depois, em 1756 , ele passara a lecionar seu curso de geografia física ${ }^{7}$, possivelmente motivado pela ocorrência do Terremoto de Lisboa, que "[...] fez com que a questão da teodicéia, da justificação de Deus ante o sofrimento humano no mundo, se tornasse muito discutida em toda Europa" (HÖFFE, 2005, p. 9). Principiava-se, assim, seu saliente interesse pelo estudo da superfície da Terra, que, não obstante, irá lhe fazer escolta até o término de sua produção intelectual.

Também em 1756, Kant redige sua Monadologia Física, obra que denuncia seu vínculo ainda acentuado com Leibniz. E isso é compreensível, pois, por mais que Kant tivesse, até o momento, concebido seu conceito de mundo reservando às forças newtonianas um papel essencial, ele observava, a exemplo de Leibniz, certa carência metafísica em Newton. E a idéia de mônada, certamente, preenchia essa lacuna.
A partir da década de 1760, Kant se ocupa em escrever textos consagrados ao exame de alguns dos problemas clássicos da metafísica ${ }^{8}$ e, gradualmente, demonstra um afastamento ante a doutrina metafísica racionalista de Leibniz e Wolff, e a dos seus seguidores Baumgartem, Crusius, etc. Kant, por conseguinte, adentra a década de 1770 um tanto quanto longínquo dos leibnizianos, hirtamente abraçado à filosofia natural de Newton e, ainda, largamente despertado pela teoria inglesa do conhecimento (David Hume). E, peregrinando em direção à filosofia crítica, ele redige sua Dissertação intitulada Sobre a forma e os princípios do mundo sensível e do mundo inteligível (1770), que se apresenta, precisamente, como uma propedêutica à metafísica (HÖFFE, 2005).

A Dissertação de 1770 exibe relevantes pedestais da crítica transcendental da razão. Nela, por exemplo, Kant já institui um corte radical entre o conhecimento sensível das coisas tal como aparecem e o conhecimento inteligível das coisas tal como são. Do mesmo modo, ele afixa que o conhecimento dos fenômenos é um conhecimento inteiramente verdadeiro; que a intuição não é um conhecimento confuso, mas uma fonte genuína de conhecimento; que as representações de espaço e de tempo não se originam dos sentidos; que é a matemática pura que investiga a forma de todo o nosso conhecimento sensível; que, do ponto de vista do método, devemos evitar que o conhecimento sensível ultrapasse os seus limites e afetem o conhecimento intelectual (HÖFFE, 2005).

Interessa-nos avivar, maiormente, que, nessa sua Dissertação, Kant assume um resoluto compromisso com Newton, sobretudo com seu conceito de espaço absoluto. É no Parágrafo 15 da Seção III de sua Dissertação, que Kant (2005) afirma que:

1) o conceito de espaço não é abstraído de sensações externas;

2) o conceito de espaço é representação singular que compreende tudo em si;

3) o conceito de espaço é intuição pura;

4) o espaço não é algo objetivo e real, mas é subjetivo e ideal;

5) o conceito de espaço é verdadeiro e o fundamento de toda verdade na sensibilidade externa; 
6) o espaço é um princípio formal do mundo sensível absolutamente primeiro.

Fica, assim, manifesto nesses itens que Kant garante o caráter absoluto do espaço definindo-o como absolutamente primeiro, universal e como que esquema e condição de tudo o que é sensitivo no conhecimento humano.

A aceitação do conceito de espaço absoluto preceitua uma forçosa anuência às teses de Newton sobre a imutabilidade da natureza e a destruição do cosmos. Contudo, onze anos (de corpulenta e ardilosa meditação) ainda se decorreriam até que o paradigma geométrico-matemático newtoniano fosse categoricamente congregado por Kant numa fundamentação filosófica, epistemológica e cosmológica até então jamais vista. E isso ocorre em maio de 1781, quando vem a público um dos edifícios majestosos do pensamento Ocidental: a Crítica da Razão Pura; obra em que Kant projeta sua ciência essencial filosófica, por ele denominada de filosofia transcendental crítica, e estabelece, quiçá, o corte mais profundo na história da filosofia moderna (HÖFFE, 2005).

A Primeira Crítica é a mais newtoniana entre todos os escritos de Kant. Ela é o paradigma matemático-geométrico de Newton realizado na forma de uma epistemologia da racionalidade humana, ou, de uma teoria da filosofia. Essa obra institui uma nova posição do sujeito em relação à objetividade e, ao efetivar "[...] o autoexame e a autolegitimação da razão independente da experiência" (HÖFFE, 2005, p. 38), o estilo newtoniano opera, em sua estrutura, como o arquétipo de um conhecimento da razão que, mesmo fundado no mundo objetivo, impetra sua transcendentalidade em conseqüência de seu caráter necessário e universal. A ciência newtoniana, deste modo, exerce a atividade de amostra de uma idéia de razão pura como princípio regulativo a serviço da experiência.

Se a razão funciona como um princípio regulativo que subjuga a experiência e se, para Kant, a necessidade e a universalidade pertinentes ao conhecimento objetivo não brotam dos objetos, mas se devem ao sujeito cognoscente, a apreensão do mundo objetivo só se realiza, então, pela razão transcendental. E como fica a natureza frente a esse esquematismo universalizante do Entendimento?
Ela resta tratada segundo a orientação substancial da Primeira Crítica:

[...] uma teoria filosófica do ente, ou seja, daquilo que um objeto é objetivamente, só pode ser elaborada [...] como teoria do conhecimento do ente, e uma teoria do conhecimento apenas como determinação do conceito da objetividade do objeto (HÖFFE, 2005, p. 45).

Ou seja, a natureza é abordada sob os auspícios de uma ciência pura da natureza, pois é apenas esta última que pode desvelar seu funcionamento mediante conceitos necessários e universais. Dessa forma, além de conceder primazia ao saber da ciência natural matemática (e ao saber da matemática), Kant ainda o fundamenta filosoficamente, subjugando-o à razão transcendental. E uma parte notável dessa fundamentação kantiana da ciência natural geral (e da matemática) encontra-se em sua estética transcendental, definida como a ciência dos princípios da sensibilidade.

$\mathrm{Na}$ exposição metafísica da estética transcendental, Kant estabelece o tempo e o espaço como formas puras da intuição. Já em sua exposição transcendental, ele assevera que essas formas tornam possível o conhecimento sintético a priori. Kant, ao situar o tempo e o espaço no universalismo a priori da sensibilidade, está acordando, abertamente, com as noções newtonianas de tempo e espaço absolutos ${ }^{9}$. Pois, é exatamente buscando encontrar uma realização conceitual que fundamentasse teoricamente a inevitabilidade do conceito de espaço absoluto, que Kant lança mão da noção de espaço como uma forma da intuição. Porém, em Kant, o espaço deixa de ser um sensorium de Deus (como pensava Newton) e passa a ser um sensorium do homem, uma forma humana da intuição.

A adesão ao espaço absoluto de Newton conduz Kant, em sua Primeira Critica, a abraçar a tese da imutabilidade da natureza. Como grifamos antes, a estética transcendental define os princípios a priori da sensibilidade. Para Kant, nosso conhecimento se relaciona com os objetos mediante a intuição, e esta nos permite perceber um particular imediatamente. A intuição supõe um 
objeto dado; e a possibilidade de os objetos nos serem dados reside na sensibilidade. Logo, não há intuição sem sensibilidade e nem entendimento sem sensibilidade. Todavia, só a recepção dos objetos não é capaz de produzir conhecimento. Para que haja conhecimento, é preciso o uso de conceitos, pois são eles que possibilitam ordenar o fenomênico segundo regras. A sensibilidade nos concede os objetos; mas é o entendimento quem os pensa (HÖFFE, 2005).

Instituindo a diferença entre a sensibilidade e o entendimento, Kant fixa que a multiplicidade indeterminada da intuição precisa ser determinada. Ainda na Primeira Crítica, Kant, define outra faculdade, a do conhecimento: o juízo, que é quem "[...] decide se a multiplicidade dada da intuição cai ou não sob a regra gerada do entendimento" (HÖFFE, 2005, p. 112). É o juízo, assim, quem autoriza a aplicação correta dos conceitos. Mas, para que o juízo consiga combinar os conceitos com os objetos dados na intuição, ele carece de uma representação que seja intuição e conceito; e Kant a nomeia de esquema. É o esquema que permite que as intuições sejam adaptadas aos conceitos e vice-versa; e é ele, ainda, que permite agrupar a multiplicidade do empírico num conceito universal.

Essa universalidade do conceito, abrigada no esquematismo do entendimento, é que possibilitaria o estudo científico da natureza. Desse modo, Kant subjuga a natureza às leis a priori dadas pela razão pura. E, nesse sentido, a empiricidade e a heterogeneidade da natureza se perdem num mero agregado de formas, numa mera generalização garantida pela aplicação das categorias ao múltiplo do empírico (KANT, 1998).

Essa idéia de natureza, confinada à aplicação do juízo determinante (que indica, a priori, uma lei, com vistas a poder subordinar o particular da natureza ao universal), apóia-se no pressuposto newtoniano da imutabilidade. Kant, em sua Primeira Crítica, corrobora o princípio de permanência da substância (HÖFFE, 2005), sem o qual não seria possível um conhecimento da natureza. Para ele, os diversos fenômenos do mundo nada mais seriam do que qualidades variantes do permanente (HÖFFE, 2005).

Kant, dessa maneira, a exemplo de Newton, não admite a representação da mudança sem um marco fixo de referência (HÖFFE, 2005). Daí, a aceitação das noções newtonianas de espaço e tempo absolutos, e da tese da imutabilidade da natureza. Pois, a idéia de imutabilidade ou de permanência "[...] é a condição imprescindível sob a qual unicamente os fenômenos podem chegar à unidade necessária de uma experiência" (HÖFFE, 2005 , p. 129). Em Kant, portanto, assim como em Newton, tudo aquilo que muda é permanente. Essa defesa da imutabilidade da natureza reitera-se na "segunda edição" da Crítica da Razão Pura (1787), quando Kant conclui o princípio da permanência afirmando que a quantidade da substância não aumenta e nem diminui na natureza.

Por fim, cabe salientar que a forte ascendência do modelo newtoniano na Primeira Crítica de Kant se revela ainda em outros dois segmentos: no princípio da causalidade e na destruição do cosmos. Para Kant, e para Newton, segundo "[...] o princípio da causalidade, só há experiência como cognição de relações naturais de causa-efeito; não pode haver intervenções sobrenaturais em processos naturais, ou seja, milagres" (HÖFFE, 2005, p. 132). Assim, a objetividade da experiência é constituída por meio da relação causa-efeito.

Essa idéia de causalidade se manifesta na crítica da cosmologia transcendental operada por Kant. Ele, na Crítica da Razão Pura, conclui que as idéias cosmológicas não têm um significado constitutivo, mas apenas regulativo. Ou seja, elas não "[...] dizem como o mundo se mostra no seu todo, mas indicam uma regra para orientar a investigação da natureza a fim de alcançar um amplo conhecimento" (HÖFFE, 2005, p. 156).

Desse modo, apreender o mundo enquanto uma totalidade absoluta em si não passaria de uma ambição nula, já que tal busca seria engravidada de uma contradição da razão especulativa consigo mesma, quando esta ousa exceder os limites da experiência. Assim, Kant declara "[...] fora de uso os conceitos metafísicos relativos ao mundo" (CLAVIER, 1997, p. 7, tradução nossa) e, com isso, manda "[...] os conceitos cosmológicos ao cemitério das hipóteses metafísicas" (1997, p. 8, tradução nossa).

Nesses termos, Kant, em sua Primeira Crítica, nega, em absoluto, a possibilidade de uma 
cosmologia enquanto uma apreensão do mundo como totalidade em si, e só a considera como uma potência irrestrita que consente o estudo sobre a natureza em suas infindáveis particularidades. Além do mais, ele acolhe o sistema de mundo de Newton, que sepulta a idéia de cosmos quando fixa o nexo sistemático do mundo num amálgama matemático (e mecânico) e não num fundamento metafísico.

Portanto, em sua Crítica da Razão Pura, Kant une-se, determinantemente, com a imagem newtoniana de natureza; versando esta última como um corpus imudável - submisso aos cânones da Razão e ao esquematismo do entendimento - cuja plasticidade é arquitetada pelo sujeito transcendental. Igualmente, ele comunga com a tese da imutabilidade da natureza, com a noção de espaço absoluto e com a idéia de sistema de mundo. E, assim, remata-se a primeira fase de Kant. E Newton exibe-se em seu cume ${ }^{10}$.

\section{Cosmologia, natureza e espaço na segunda idade da filosofia transcendental kantiana}

Quando da publicação de sua Primeira Crítica, em 1781, Kant já acumulava mais de vinte anos de seus ensinos de geografia física. Suas lições de geografia física - que pareciam verdadeiras conferências populares - miravam oferecer um catálogo ideográfico dos quadros do mundo; um inventário raciocinado da superfície da Terra; uma propedêutica do conhecimento do mundo; uma descrição da Terra inteira, ou, um conhecimento do mundo (KANT, 1999b).

Seguramente, a heterogeneidade das formas terrestres mostrada pelas lições de geografia física impeliu Kant a meditar sobre a posição por ele outorgada à natureza no esquematismo do entendimento. Pois, a particularidade da natureza, revelada por seus conteúdos espaciais não uniformes, ficava extraviada nas generalizações simétricas da razão totalizante. Além disso, J.G. Herder (1744-1803) - que, aliás, cursou a geografia física de Kant - e J.G. Forster (1754-1794), denunciaram a insuficiência deste esquematismo para explicar seja a diversidade da natureza, seja a diversidade da história. Assim, Kant vê suas noções de espaço e de natureza - largamente escoradas no pressuposto newtoniano da imutabilidade da natureza, austeramente replicadas.

Kant nunca hesitou em reinventar-se, isto é, em revolucionar suas próprias idéias, alargandoas, ressignificando-as e aprofundando-as tomando como pujança a plasticidade e a fertilidade do âmago crítico que as alimentavam. Exemplo disso é que - atendendo às férteis réplicas de Herder e Forster, bem como à heterogeneidade da natureza exibida por seu ensino de geografia física - Kant dedica-se, a partir da segunda metade da década de 1780 , a instituir um novo modelo de explicação da natureza.

Em seus Princípios Metafísicos da Ciência da Natureza (1786) ${ }^{11}$, Kant ainda delata um corpulento comprometimento com o modelo geométrico de Newton, sobretudo por atestar a existência de princípios regulativos (e mecanicistas) na natureza e a noção newtoniana de causalidade. Kant, também, faz uso dos conceitos newtonianos de matéria, massa e de movimento, além de adotar, inteiramente, os princípios da dinâmica e da mecânica firmados por Newton ${ }^{12}$. Essa obra, portanto, ainda guarda uma íntima correlação com a estrutura explicativa da Crítica da Razão Pura. Tanto é que Kant define a metafísica particular da natureza como uma aplicação dos princípios transcendentais, fixados na Primeira Crítica, ao gênero dos objetos do sentido externo, ou seja, à matéria.

Da mesma forma, Kant - no prefácio aos Princípios Metafísicos - reitera, a exemplo da Primeira Crítica, que a metafísica geral, sempre que necessita de exemplos (intuições) para procurar um significado dos conceitos puros do entendimento, tem que tomá-los da teoria geral dos corpos, ou seja, da forma e princípios da intuição externa. Igualmente, ele atesta que a categoria, por si só, não nos permite compreender a possibilidade de nenhuma coisa. Por isso, sempre temos a necessidade de uma intuição para descobrir a realidade objetiva do conceito puro do entendimento. Assim, para compreender a possibilidade das coisas pelas categorias e, por conseguinte, para provar a realidade objetiva destas últimas, temos sempre necessidade não só 
de intuições, mas também de intuições externas.

Desse modo, para Kant, a prova da realidade objetiva das categorias só se estabelece em conexão com a forma e princípios da intuição externa. Por isso, a metafísica geral mostra-se estéril enquanto não se exponha completamente a teoria geral da natureza corpórea. A razão pura tem que se remeter com seus princípios à natureza e empreender, assim, o que a razão mesma busca nela de acordo com o que dela deve aprender, porém que por si só não poderia saber. Mais do que determinar o que a razão pode conseguir por si própria, deve-se também determinar quando sua capacidade começa a ter necessidade de recorrer aos princípios da experiência. Por isso, para Kant, uma metafísica corpórea - ou seja, uma metafísica da natureza - é indispensável para a metafísica geral.

Contudo, essa obra - apesar de sua íntima correspondência com a Crítica da Razão Pura e ainda subjugada ao uso de princípios regulativos para a explicação da natureza - incita Kant a colocar a si mesmo algumas inquirições: Como transformar estes princípios regulativos em conhecimento? Como ligar estes princípios regulativos a um princípio transcendental? Como a natureza dividese em partes? Como o universal pode ser diferente? Como apreender o universal no particular?

Na constituição de réplicas a tais inquirições, Kant é compelido a romper com Newton e com sua tese da imutabilidade da natureza. Objetivando justamente reformar a imagem de natureza (para além de uma conformação subjugada às imposições simétricas da Razão) e resolver a contradição entre os princípios regulativos e o princípio transcendental, Kant entrega-se a escrever sua Crítica da Faculdade do Juízo (1790) ${ }^{13}$.

A Crítica da Faculdade do Juízo, que foi originalmente publicada em 1790 e representa a culminação da filosofia transcendental de Kant (MARQUES, 1998). Ela faz parte de um todo, que kant chamou de sistema crítico e simboliza o esforço último deste filósofo em designar, definitivamente, os limites e o perfil da nossa faculdade de conhecimento. Kant formulou sua Terceira Crítica em razão de algumas lacunas por ele sentidas. Lacunas estas não simplesmente deixadas por alguma incompletude subjacente às
Críticas anteriores, mas ingênitas à completude (e às necessidades) de um sistema do qual elas faziam parte (MARQUES, 1998).

$\mathrm{Na}$ verdade, Kant, no anoitecer de sua atividade intelectual, sente a necessidade de buscar elementos mediadores para minimizar corpulentos dualismos fixados pelo seu pensamento: entendimento $x$ sensibilidade; entendimento $x$ razão; razão prática $x$ razão teórica. Ele afirma que à razão interessa que as idéias tenham realidade objetiva; que a natureza pelo menos mostre um vestígio ou nos avise que ela contém, em si, algum fundamento. Assim, a liberdade e as exigências da razão prática em geral, para Kant, serão mais bem confirmadas por uma natureza que contenha, ela própria, determinados traços de inteligência e que se mostre adequada aos fins do homem (MARQUES, 1998).

Dessa forma, toda a temática da Terceira Crítica relaciona-se com essa espécie de adequação da natureza à razão humana em função daquilo que a ela lhe interessa, isto é, a liberdade e os princípios racionais que esta determina. Esse problema da aproximação entre os domínios da natureza e os da liberdade conduz a um interesse renovado de Kant pela própria natureza. Destarte, Kant, na Crítica do Juízo busca, notadamente, reconstruir a imagem da natureza resultante da Crítica da Razão Pura (MARQUES, 1998).

Isso significa que, em sua Terceira Crítica, Kant expõe um modelo de inteligibilidade da natureza radicalmente distinto do da Primeira Crítica. Na Crítica do Juízo, a natureza é entendida para além de um mero agregado de formas ou de um amontoado de leis particulares que explicam este ou aquele fenômeno isoladamente; logo, ela é julgada de uma perspectiva substancialmente diferente daquela que correspondia ao uso das categorias, próprio da Crítica da Razão Pura.

Assim, na Terceira Crítica, Kant busca desvelar dependências entre a natureza e a liberdade. Por mais que considere haver um abismo intransponível entre o domínio do conceito de natureza (enquanto sensível) e o do conceito de liberdade (como suprassensível), Kant afirma que o conceito de liberdade deve ter uma influência sobre o conceito de natureza, isto é, o conceito de liberdade deve tornar efetivo no mundo dos 
sentidos o fim colocado pelas suas leis e a natureza tem, conseguintemente, que ser pensada de tal modo que a conformidade a leis da sua forma concorde pelo menos com a possibilidade dos fins que nela atuam segundo leis da liberdade (MARQUES, 1998).

Instituir essa conexão entre natureza e liberdade depende da descoberta de um princípio pelo qual nossos juízos sobre a natureza não se restrinjam a uma espécie de subsunção automática dos casos particulares nos nossos conceitos mais gerais. Estabelecer essa conexão pressupõe uma nova maneira de apreender a relação entre o particular e o universal. Desse modo, Kant, em sua Terceira Crítica, não excede ao esquematismo do sujeito transcendental firmado na Primeira Crítica. O que ele faz é aproximar o sujeito da dinâmica da vida sensível e afetiva. Assim, ele amplia os fatores de produção de inteligibilidade do sujeito transcendental, mediante a introdução de componentes afetivo-vivenciais, sem sucumbir a um subjetivismo a-conceitual e redutor (MARQUES, 1998). Seria, então, um desacerto atribuir à Crítica do Juízo a edificação de uma filosofia do sentimento ou da afetividade fora do alcance dos pressupostos críticos já adquiridos.

Nesse sentido, Kant atribui um labor mais livre à faculdade do juízo, o que possibilita, entre outras coisas, múltiplas modalidades segundo as quais pode-se abordar a natureza: como se ela possuísse uma técnica que a diferencie, nos seus produtos, em gêneros e espécies; como se possuísse princípios de unidade nas suas múltiplas leis adequadas às faculdades do sujeito; como se algumas das suas formas possuíssem qualidades tais que nos provocam um sentimento de prazer (estético). Essa diversidade de modos de situar a natureza indicia uma regra ou princípio no cerne da faculdade do juízo. Trata-se do princípio da especificação da natureza. Esse princípio, que Kant dá um valor transcendental e não meramente lógico, é algo que a faculdade do juízo dá a si própria.

A natureza, destarte, não se exibe mais circunscrita aos cânones de uma razão que se realiza enquanto um princípio regulativo. Por isso, Kant, em sua Crítica do Juízo, busca fixar outro princípio transcendental para além das categorias do entendimento e da lei moral da razão prática. E é aí que assume relevo o sentimento de prazer e desprazer. Kant, assim, é levado a associar a idéia de prazer com o próprio juízo. Concretamente é naqueles juízos em que a regra (lei, categoria ou princípio) que vai subsumir o particular tem de ser descoberta, e a que Kant chamou reflexivos em oposição àqueles em que a regra já está dada de partida, isto é os determinantes que intervém o elemento do prazer. E esse sentimento, Kant define-o a partir do conceito de conformidade- afins da natureza, que exercerá enorme influência em Goethe em Alexander von Humboldt (VITTE, 2008).

Este é o princípio que então faltava ao quadro dos princípios transcendentais da filosofia de Kant. Kant consegue, no interior desse ponto de vista geral que é a conformidade-a-fins, realizar uma distinção essencial (consoante essa conformidade possua ou não um interesse cognitivo). É assim que é possível falar de uma conformidade-a-fins, tanto de um ponto de vista estético (subjetivo) quanto de um ponto de vista teleológico (objetivo). Numa crítica da faculdade de juízo a parte que contém a faculdade do juízo estética é aquela que Ihe é essencial, porque somente esta possui um princípio inteiramente a priori na sua reflexão sobre a natureza (MARQUES, 1998).

Na Terceira Crítica institui-se uma ligação entre o sentimento de prazer e desprazer e a conformidade-a-fins da natureza, e tal ligação constitui-se como um pressuposto de todo o julgamento reflexivo (não automático ou categorial no sentido da Primeira Crítica). Eis, então, a introdução do elemento do prazer tanto na experiência estética como também na experiência cognitiva da construção teleológica da natureza. Kant, assim, aproxima a experiência estética da teleológica num mesmo sentimento de prazer.

Assim, Kant parece querer estender uma legislação suprassensível ao domínio da natureza. As formas da natureza (as belas formas e as formas orgânicas) exerceriam uma espécie de pressão para a reflexão, ou seja, obrigariam o sujeito transcendental à escolha de certos pontos de vista que alargariam suas perspectivas firmadas na Crítica da Razão Pura. A Primeira Crítica, aliás, não 
se preocupava com a particularidade do particular.

E a questão central da Terceira Crítica se situa na tentativa de resolver a distância sem mediações entre a singularidade dos particulares e o interesse dos pontos de vista categoriais, e, ainda, a atividade de uma imaginação cuja atividade se esgota nas operações de subsunção do particular no geral. Aliás, é possível afirmar que o cerne da teoria da reflexão na Terceira Crítica se encontra numa diferente mobilidade dada à faculdade de imaginação no conjunto das demais faculdades. A imaginação, portanto, entra num jogo com as outras faculdades intelectuais: a razão e o entendimento ${ }^{14}$

Podemos, então, afiançar que na Terceira Crítica, Kant rompe com o paradigma matemático-geométrico de apreensão da natureza, quando aparta esta última dos cânones do juízo determinante e a submete ao juízo reflexivo. Enquanto que na Primeira Crítica Kant fez com que o entendimento prescrevesse-se com um a priori, ou seja, como lei para a natureza. Tomando esta apenas como um complexo de fenômenos, cuja forma seria dada igualmente a priori. Logo, o entendimento indicaria a priori as condições da possibilidade de todas as coisas que ele poderia conhecer e, ainda, determinaria a possibilidade de todas as coisas em geral. A Terceira Crítica, ao contrário, permitiria à reflexão escolher outros pontos de vista que não só os correspondentes às categorias supremas do entendimento. Pois, superar o esquematismo das categorias é algo que só pode resultar de uma autonomia do sujeito, que Ihe permite usar novos pontos de vistas para além da explicação categorial.

Dessa maneira, na Terceira Crítica, influenciado fortemente por Herder e noticiando a existência de outra faculdade (o juízo) entre a razão e o empírico, Kant reconheceu que a natureza tem uma história e que há uma dinâmica, uma transformação, enfim, uma epigenia na natureza e em suas formas. E isso o conduz a ressignificar suas idéias de espaço e de natureza. Espaço e natureza começam, a partir de então, a afluir, pois o primeiro passa a ser compreendido não só como uma mera idealidade (ou representação), mas também como uma materialidade. E essa materialidade do espaço se prende a uma nova idéia de superfície da Terra e, conseguintemente, de geografia física.

A geografia física, realiza nesse novo momento da obra kantiana, o projeto de arquitetar uma representação dos conteúdos espaciais da natureza, cuja ordenação e plasticidade retratam a reunião sintética dos princípios regulativos e, também, de buscar encontrar o universal no particular, mediante uma aproximação com a história da natureza, que permite a apreensão transcendental da dinâmica da natureza enquanto universalidade.

No acontecer desse cometimento, Kant é levado a repensar o sistema-mundo newtoniano e a procurar reconstruir uma cosmologia. $\mathrm{E}$, nessa contextura, a superfície da Terra passa a ser a representação de uma síntese espacial produzida pela conformidade entre princípios regulativos, a idéia de causalidade e o funcionamento universal e dinâmico da natureza em seu devir.

\section{O Curso de Geografia Física de Kant, a Modernidade e a constituição de uma ciência geográfica}

"[...] o espaço não tem somente por função dissociar no modo da justaposição o que, ficado na 'cabeça' teria ficado confundido; o espaço geográfico, cuja especificidade Kant nos convida a pensar, não é esta realidade absoluta onde as diferenças se extrapolam, mas o porque os objetos da experiência são experiência de objetos" (COHEN-HALIMI, 1999).

A ciência geográfica, como realçamos na abertura desse artigo, vem à luz na contextura do gradual, intricado e dialético processo de reinvenção do mundo que se concretiza no florescer da experiência moderna. Essa reinvenção abrolha de abissais transformações ocasionadas na dinâmica de reprodução sócioespacial do metabolismo societário do capital e, ao mesmo tempo, de uma profunda reconstrução metafísica dos conceitos de substância, de matéria, de espaço, de natureza e de causalidade.

A Geografia, assim sendo, imputa sua identidade, na modernidade, proporcionando e 
irradiando uma cosmovisão moderna. Ou seja, ela alcança sua legitimação científica colocando em ordem, o múltiplo do empírico, da experiência moderna em um amálgama metafísico, isto é, reinventando a imagem de superfície terrestre. Nesses termos, a conexão entre a construção da ciência geográfica e a modernidade é claramente inconcussa.

Immanuel Kant exibe-se como um dos mais importantes representantes do saber geográfico na nova tessitura instaurada pela experiência moderna. Esse eminente pensador alemão, amplamente reconhecido como um dos mais egrégios arquitetos da filosofia moderna, legou, salientes contribuições à compleição da ciência geográfica. Todavia, tais tributos restam, geralmente, sujeitos ao critério da obliqüidade.

Desse modo, assumimos, nesse artigo, que há uma consangüinidade metafísica entre o projeto da modernidade, a filosofia e a geografia formulada por Immanuel Kant. Onde a geografia impetra sua validação científica justamente ao outorgar uma cosmologia aos espaços renovados da modernidade, Kant destaca-se como um dos principais artesãos dessa empresa, essencialmente moderna, de reconstrução metafísica da idéia de mundo.

Kant, nesse sentido, especialmente em sua sublime Crítica da Faculdade do Juízo (1790), ao buscar edificar um modelo de inteligibilidade da natureza, face ao paradigma matemáticogeométrico newtoniano, acabou por instituir a possibilidade de se apreender a particularidade das formas da natureza a partir da aplicação do juízo estético e do juízo teleológico, permitindo pensar o mundo enquanto uma totalidade orgânica, cujas partes se conformam no quadro geral da superfície terrestre.

Não por acaso, a Terceira Crítica kantiana, notadamente no que diz respeito aos seus conceitos de conformidade-a-fins, de juízo estético, de juízo reflexivo e de juízo reflexionante, exerceram saliente influência em Schiller e em sua concepção estética; em Goethe, notadamente em sua concepção de morfologia, sem falar em Alexander von Humboldt que, mediante a ideia de conformidade-a-fins, estabeleceu o conceito de conexão e, apoiado na idéia goetheana de morfologia, institui a noção de espacialidade (VITTE, 2008; VITTE et alli, 2009).

Dessa maneira, a importância da filosofia kantiana na formação epistemológica da ciência geográfica é de abstrusa mensuração. Além do mais, Kant legou contribuições indeléveis à própria constituição da geografia enquanto um discurso reconhecidamente científico, especialmente com seu Curso de Geografia Física. Ao definir, nas páginas desse curso, o espaço como objeto de estudo da Geografia, ele autorizou essa disciplina a atingir a variedade e a empiricidade da natureza em sua totalidade e, deste modo, a oferecer uma imagem atualizada do mundo moderno. Eis, assim, o estímulo terminante para a geografia elevar-se aos ares de uma especialidade científica.

\subsection{Os conteúdos do Curso de Geografia Física de Kant: o conceito de espaço como o amálgama de validação de uma ciência geográfica}

Kant lecionou geografia física por quase quarenta anos. Ele próprio assevera que, por mais de três décadas, ofereceu dois cursos que tinham por alvo a consciência do mundo: a Antropologia (durante os semestres de inverno) e a Geografia Física (durante os semestres de verão). Suas notas utilizadas no curso de Antropologia foram conservadas e devidamente publicadas. Todavia, as notas por ele empregadas no curso de Geografia Física não foram sistematizadas e organizadas, ao seu modo, em uma publicação.

Kant nunca negou o valor de oferecer ao público essas suas preciosas anotações; ele apenas considerava o trabalho de retomada das mesmas de impossível realização, sobretudo em razão do findar de sua vida. Foi, então, que ele atribuiu tal trabalho a um de seus antigos alunos, Thomas. Rink, e, este, a partir de três cadernos encontrados na residência de Kant, publicou, em 1802, parte dessas notas do Curso de Geografia Física.

Não é uma empresa simples interpretar o Curso de Geografia Física de Kant, pois se trata de um livro inacabado e sem acabamento possível; de um curso antes que livro; de uma palavra escrita que se soma a outros discursos: narrativas de 
missionários, de navegadores, de exploradores, tratados antigos e modernos sobre o estado da Terra; de um livro feito de outros livros e, muitas vezes, re

trabalhado por informações sempre novas, por leituras continuadas, por hipóteses confirmadas e infirmadas à medida de experiências renovadas (COHEN-HALIMI, 1999).

O que não hesitamos em asseverar é que, mesmo tendo acompanhado clandestinamente todo o percurso filosófico de Kant, já que ele só foi editado tardiamente, o Curso de Geografia Física é parte integrante da herança intelectual kantiana. Ele, destarte, está longe de ser uma mera coleção de coisas marginais ou uma obra marginal; e escolta, intimamente, o sistema crítico e a reflexão do Aufklärer de Königsberg.

O Curso de Geografia Física mostra-se como um inventário do mundo, que buscava trazer aos estudantes um conhecimento vasto e preciso de tudo o que se sabia existir na superfície da Terra. Por isso, o discurso de Kant é ora positivo, densamente ligado às coisas naturais, leal aos seus detalhes, sendo absorvido pela descrição e dirigido às tarefas de exibição e de explicação, ora negativo incluindo uma atividade de julgamento, que ora acolhe os preconceitos os mais infames, ora pesa e suspende cada opinião, o enunciado e o retrato. Há, assim, não somente uma palavra do geógrafo Kant, mas duas: uma que coleta, compila e relata e, outra que escolhe, suspende e duvida (COHEN-HALIMI, 1999).

Existe, portanto, uma atividade de julgamento própria ao Curso de Geografia Física. Pois, para Kant, não se podia contentar em olhar o mundo como um objeto do sentido externo. Faziase imprescindível, segundo ele, um trabalho de ligação das experiências relatadas. Desse modo, parece-nos razoável estabelecer uma aproximação entre as notas do Curso de Geografia Física com a Crítica da Faculdade do Juízo de Kant.

Como vimos anteriormente, o decurso filosófico de Kant experimenta rugosidades. Depois de iniciar sua trajetória intelectual sob forte influência dos leibnizianos, o filósofo de Königsberg abraça o estilo newtoniano enquanto um modelo de interpretação da natureza e de produção do saber científico ele mesmo. Esse liame com Newton encontra sua expressão maior em sua Crítica da Razão Pura, obra em que Kant adota, abertamente, os preceitos newtonianos da imutabilidade da natureza e da destruição do cosmos.

Em sua Primeira Crítica, a natureza mostrase rigidamente subjugada ao esquematismo do entendimento. Mediante o uso irrestrito de princípios regulativos e do juízo determinante, a natureza não era nada senão o que o próprio entendimento prescrevia, a priori, às suas formas e à sua dinâmica. Nesse sentido, a natureza não era apreendida em sua heterogeneidade e em sua empiricidade. A particularidade do particular da natureza ofuscava-se ante a simetria totalizante do Entendimento.

Do mesmo modo, confinado aos conceitos newtonianos de matéria, de movimento, de causalidade e de espaço absoluto, Kant adotou a idéia de sistema de mundo, ao prescrever o mundo enquanto um agregado cujo nexo fundava-se na universalidade da lei da gravitação, ou seja, num amálgama meramente físico-mecânico e não metafísico.

As próprias lições de geografia física, somadas às críticas provenientes de Herder e Forster, incitaram Kant a, gradualmente, consentir-se e impor-se construir um novo modelo de inteligibilidade da natureza. Em 1786, com seus Princípios Metafísicos, apesar de seu forte comprometimento com Newton e com a Primeira Crítica, ele já enceta os esboços de um rompimento efetivou-se na Crítica da Faculdade do Juízo. O próprio Kant (1998), definiu a faculdade do juízo como a faculdade de pensar o particular como contido no universal. Essa faculdade pode ser determinante quando, pelas categorias do entendimento, apenas se subsume o particular ao universal ou reflexiva quando só o particular é dado e se deve encontrar o universal.

A natureza, nesses termos, passa a ser entendida mediante uma dilatação das faculdades do conhecimento. A noção de juízo permite incorporar, aos estudos da natureza, as dimensões estéticas e teleológicas. Ante o sistema de mundo newtoniano, Kant redescobre a necessidade de arquitetar um cosmos, que seja capaz de romper com o nexo mecânico do mundo e fixar um nexo orgânico da totalidade teleológica da superfície da 
Terra. Essa construção, a de uma outra imagem de natureza conduz Kant a ressignificar o conceito de espaço. Ante o espaço absoluto de Newton, ele recupera a noção leibniziana de espaço enquanto uma coexistência de entes. O curso de geografia física de Kant espelha, em seus conteúdos, essa nova concepção de cosmos, de natureza e de espaço.

Kant na Introdução de sua geografia física, inicialmente, afirma que as fontes e a origem de nosso conhecimento encontrar-se-iam na razão pura ou na experiência. Desse modo, "Os conhecimentos puramente racionais são dados por nossa razão; em compensação, é pelos sentidos que nós recebemos os conhecimentos empíricos" (KANT, 1999b, p. 65, tradução nossa). Como nós possuímos um duplo sentido, "[...] um sentido externo e um sentido interno, graças a eles, nós podemos considerar o mundo como soma de todos os conhecimentos empíricos" (1999b, p. 65, tradução nossa). Como objeto do sentido externo, o mundo é a natureza; como objeto do sentido interno, ele é o homem ou a alma.

Segundo Kant, "As experiências que nós temos da natureza e do homem constituem os conhecimentos do mundo" (1999b, p. 66, tradução nossa). A antropologia, assim, nos ensinaria o conhecimento do homem; a geografia física (ou descrição da Terra) nos ensinaria o conhecimento da natureza. Logo, a "[...] descrição física da Terra é, pois, a primeira parte do conhecimento do mundo. Ela pertence a uma idéia que nós podemos nomear a propedêutica do conhecimento do mundo" (1999b, p. 66, tradução nossa).

Nessas primeiras considerações, fica evidente que Kant trata a geografia física como um conhecimento empírico, cujo objeto, a natureza que é apreendida pelo sentido externo. Ela, a geografia física, seria, nesses termos, a propedêutica ao conhecimento do mundo, sendo este, também, objeto do nosso sentido externo. Como a geografia física necessita da experiência, e, como nós, em razão de nossa limitada existência, necessitamos da experiência do Outro para abrangermos a totalidade do mundo, Kant assevera que toda experiência "estranha" (do Outro) é-nos transmitida de dois modos: sob a forma de uma descrição e sob a forma de uma narração. A primeira é uma geografia; a segunda, uma história. A geografia seria, portanto, uma descrição.

Todavia, Kant apressa-se em discriminar a geografia da topografia que seria a descrição de um lugar singular da Terra, a geografia também difere da corografia que seria a descrição de uma região e de suas propriedades e, por fim, a geografia difere da hidrografia que seria a descrição das águas.

Logo, a geografia não seria uma mera descrição, mas uma descrição da Terra inteira (KANT, 1999b). Eis, então, um primeiro componente da definição de geografia em Kant: ela seria a ciência que se preocupa com a descrição da superfície terrestre em sua totalidade.

Kant, em seguida, lança-se numa segunda discriminação para definir a geografia: ele a situa numa separação entre a divisão lógica e a divisão física. Para ele, nosso conhecimento empírico pode ser designado segundo conceitos ou segundo o tempo e o espaço onde eles realmente são encontrados. Assim, "A divisão dos conhecimentos segundo conceitos é a divisão lógica, a que é feita segundo o tempo e o espaço é a divisão física" (KANT, 1999b, p. 68, tradução nossa). Pela primeira, assevera Kant, nós obtemos um sistema da natureza (como o de Linneu); pela segunda, nós obtemos uma descrição geográfica da natureza. Enquanto a classificação lógica existe, apenas, na cabeça do pesquisador, a classificação física abrange as "[...] coisas [...] segundo os lugares onde elas se acham sobre a Terra" (1999b, p. 69, tradução nossa).

A descrição geográfica da natureza, deste modo, possui a especificidade de indicar os lugares onde as coisas existem realmente. Ou seja, ela toma "[...] em consideração o teatro da natureza, a Terra em si mesma e as regiões onde se acham realmente as coisas" (KANT, 1999b, p. 69, tradução nossa). E, sobretudo, a descrição geográfica da natureza (a geografia), diferentemente do sistema da natureza que Kant afirma que, em vez de sistema, deveria se chamar agregado, consegue abranger o mundo enquanto totalidade, ou melhor, enquanto um sistema, que, por sua índole, pressupõe a idéia do todo a partir da qual é derivada a diversidade das coisas (KANT, 1999b).

Defrontamo-nos, assim, com um segundo componente da definição de geografia em Kant: 
ela seria uma classificação física da natureza, ou melhor, ela seria uma descrição da natureza enquanto um sistema (onde o todo precede as partes, diferentemente do agregado, onde a parte precede o todo).

Por fim, Kant impõe um terceiro discriminante para se definir a geografia. Diz ele: "[...] a história como a geografia podem ser chamadas todas duas uma descrição, com a diferença de que a primeira é uma descrição segundo o tempo e a segunda uma descrição segundo o espaço" (KANT, 1999b, p. 69, tradução nossa). A história abordaria os eventos que decorrem uns após os outros do ponto de vista do tempo. A geografia, por sua vez, trataria dos fenômenos que se produzem ao mesmo tempo do ponto de vista do espaço (KANT, 1999b). Nessa direção, Kant (1999b, p.70 e 71, tradução nossa) afiança:

É pois somente do ponto de vista do espaço e do tempo que a história (Historie) difere da geografia. A primeira, como eu já disse, é a relação de acontecimentos consecutivos e tem relação com o tempo. A segunda, em compensação, é a relação dos acontecimentos que se produzem uns ao lado dos outros no espaço. A história (Geschichte) é uma narração enquanto a geografia é uma descrição. Por conseguinte, nós podemos bem ter uma descrição da natureza mas não uma história da natureza. De fato, esta última denominação,da qual muito fazemos uso, é inteiramente inexata. Mas como nós temos o hábito de crer segurar a coisa quando nós temos somente o nome (IX, 162), ninguém pensa entregar realmente uma tal história da natureza.

A história da natureza contém a diversidade própria à geografia, ela mostra como as coisas estavam em diferentes épocas mas não como elas são agora a um único momento pois ela deveria então uma descrição da natureza.

A partir disso, Kant se sente em condições de exprimir sua ilação nodal: a geografia designa, pois, uma descrição da natureza, mais ainda, uma descrição da natureza da Terra inteira. E a geografia física seria um resumo universal da natureza. Esta última seria não só o fundamento da história, mas, também, de todas as geografias possíveis ${ }^{15}$.

Essas assertivas de Kant nos permitem julgar que, ele, separa a geografia tanto do saber matemático (por causas) como da tradição herdada de Estrabão (que pesquisa a superfície das coisas e produz descrições a um rigor incerto). Assim, para Kant, a geografia não seria nem um conhecimento por conceitos matemáticos, nem uma mera reunião de conhecimentos empíricos; nem parente próximo da astronomia, nem parente pobre da heredotage; nem disciplina matemática nem corografia (COHEN-HALIMI, 1999).

Kant parece observar atentamente um sério problema à geografia: ou ela se eleva à cientificidade ficando viúva de seu objeto próprio (o espaço) - subordinando-se à quantificação e à matematização - ou, ela se extravia nas linhas e superfícies infinitas de seu objeto (o espaço). Kant vai além dessas duas possibilidades, e define a geografia como uma "descrição raciocinada de tudo o que é visível na superfície da Terra".

Por fim, é importante salientar que, quando Kant discrimina a divisão lógica da divisão física, ele pretende assegurar que é o espaço que não comparece na primeira e, portanto, concede especificidade à segunda. A grande limitação do sistema da natureza (como o de Linneu) consistia, justamente, em sua incapacidade de abranger a realidade da natureza, sua empiricidade. Quando ele, portanto, classifica a geografia como parte da divisão física, ele aspira demonstrar que essa disciplina consegue apreender essa empiricidade da natureza, submetendo-a a uma totalidade. E é o espaço quem the outorgaria tal capacidade.

Além do mais, quando Kant, depois de liberar a geografia da divisão lógica, busca discriminá-la da história e da história natural, mediante a oposição "divisão física segundo o tempo/segundo o espaço", ele, mais uma vez, destaca o espaço como o elemento discriminante. É isso que o leva a afirmar que se pode ter uma descrição da natureza, mas não uma história da natureza. E o espaço, mais uma vez, é que liberta a geografia, por exemplo, do modelo de história natural buffoniano. Assim como refuta o sistema de Linneu por sua impossibilidade de aplicação ao real; ele reprova a história natural de Buffon por sua impossibilidade de alcançar a sistematicidade. 
É nesse contexto que Kant define a geografia como uma "descrição segundo o espaço". Logo, esta ciência seria uma descrição da natureza e não uma história da natureza; ela seria uma fisiografia, ou seja, uma descrição dos fenômenos e das produções da natureza e não uma fisiogonia. Assim, ele desobriga da competência do geógrafo toda arqueologia da natureza quer dizer, todo o exame do devenir das criaturas terrestres, toda pesquisa sobre as transformações diacrônicas das espécies e da Terra. Kant, assim, atribui à geografia a tarefa de levar a efeito uma descrição sistematicamente ordenada das coisas da natureza que se acham na superfície da Terra.

Essa definição de Kant traz uma novidade substancial: "a geografia seria uma descrição segundo o espaço". Essa definição, em primeiro lugar, aclara a posição de Kant frente à questão da legitimidade científica da geografia. O espaço, enquanto seu objeto seria o atributo, aos olhos de Kant, que permitiria à geografia figurar ao lado das disciplinas verdadeiramente científicas. 0 espaço é que garantiria uma geografia que não se limita às fronteiras de uma tautologia empirista; que se coloca para além de um mero compêndio de análises simplistas de relações superficiais e, assim, se eleva ao nível de abstração requerido pela ciência moderna.

E é o espaço, também, que resguardaria à geografia dois atributos fundamentais para o estudo da natureza: apreender sua heterogeneidade e sua empiricidade diferentemente de uma divisão lógica e compreendê-la enquanto um sistema diferentemente da história natural. E, se a geografia estuda o espaço enquanto algo que autoriza abranger a empiricidade da natureza, seguramente esse espaço não é o newtoniano, confinado na abolutez de sua imutabilidade, mas um espaço que se realiza enquanto materialidade e enquanto uma coexistência de seres. Ou seja, é o espaço leibniziano, que Kant retoma na Terceira Crítica.

E a geografia enquanto uma descrição das coisas da natureza que se acham na superfície da Terra compõe, precisamente, uma nova cosmologia de Kant. A própria imagem de superfície terrestre cumpre o papel de espelhar uma conexão orgânica entre as diferentes formas da natureza. A conformidade-a-fins da natureza constrói a superfície terrestre em sua morfologia. A estética e, sobretudo, a teleologia, seriam os componentes deste sistema cosmológico, que se fecha mediante uma representação da totalidade da Terra em seus diferentes arranjos espaciais.

Assim sendo, a geografia física, em Kant, cumpre distintos papéis: impulsiona, junto com outras forças, Kant a prestar atenção na heterogeneidade da natureza e, assim, incita-o a repensar um modelo de inteligibilidade da natureza para além da simetria totalizante do entendimento , ao mesmo tempo em que permite o fechamento do seu sistema cosmológico; espelhando uma nova

\section{Notas:}

1. Essa aquiescência da filosofia newtoniana pela Europa, nessa época, deve-se, sobretudo, aos resultados das expedições geodésicas realizadas, de 1735 a 1737, por Maupertuis (1698-1759). Provando ser a forma da Terra achatada nos pólos (ao comparar a medição de um meridiano no próprio equador e a medição de outro meridiano feita, por ele, na Lapônia), Maupertuis destituiu as conjecturas cartesianas (segundo as quais a Terra teria a forma de um elipsóide oval alongado no sentido de seu eixo) e, assim, permitiu a ampla disseminação da conjectura de Newton (que, num teorema dos Principia, afirmava ser a Terra um esferóide achatado nos pólos e cheio junto ao Equador) pelo continente europeu.
2. Trata-se do primeiro escrito de Kant, redigido em 1746 e publicado em 1749, intitulado: "Pensamientos sobre la verdadera apreciación de las fuerzas vivas y enjuiciamiento de las demostraciones de que se han servido el señor Von Leibniz y otros matemáticos en esta cuestión en litígio, junto con algunas consideraciones preliminares que atañen a las fuerzas de los cuerpos en general" (BOROWSKI, 1993). Nessa obra, Kant "[...] tenta encontrar uma solução de compromisso para resolver 'uma das maiores cisões entre os geômetras da Europa' [...]. Na disputa em torno do cálculo da força $(F)$ a partir da massa $(m)$ e velocidade $(v)[\ldots]$ ", ele, Kant, "[...] 
dúangeñodeasateiterizianos [...] no que concerne às 'forças vivas', isto é, aos movimentos livres. Por outro lado, ele concorda com Descartes e a sua Escola quanto às 'forças mortas', isto é, os movimentos não livres" (HÖFFE, 2005, p. 7).

3. Kant distingue dois tipos de conhecimento: um a posteriori e outro a priori. O conhecimento a posteriori seria aquele que decorre dos dados fornecidos pela experiência sensível. Já o conhecimento a priori é aquele que independe de qualquer impressão sensível, sendo um conhecimento necessário e universal (KANT, 1999a).

4. Seria um ato sem préstimo intentar fixar uma periodicidade rígida à filosofia kantiana em seu curso de efetivação. A realização da filosofia kantiana divulga-se, em seu itinerário, como um processo não-uniforme e, portanto, assinalado por rugosidades (isto é, por ocasiões coexistentes e/ou sucessivas de continuidadesdescontinuidades; interrupções-ininterrupções; rupturas-manutenções; saltos teóricos-refluxo a fontes anteriores). Contudo, mesmo conhecedores dessa fatal arbitrariedade, consentimo-nos, como recurso analítico, dividir o corpus teórico kantiano no que diz respeito, especificamente, à construção de uma concepção cosmológica de natureza - em duas grandes fases: a primeira se estenderia até 1781 (ano de publicação da Crítica da Razão Pura); a segunda, por sua vez, se cumpriria de 1786 (ano da publicação dos Princípios Metafísicos da Ciência da Natureza) até 1790 (ano de publicação da Crítica da Faculdade do Juízo). Essa divisão justifica-se pelo fato de que, até 1781 , apesar de outras ressaltantes e fundamentais influências (Leibniz, Descartes, Wolff, etc.), revela-se, em Kant (sobretudo em sua Crítica da Razão Pura), a ascendência majoritária de Newton e de suas noções de imutabilidade da natureza, de inércia e de espaço absoluto. A partir de 1786, entretanto, inicia-se uma sensível ruptura de Kant com Newton e uma gradual retomada dos preceitos de uma concepção dinâmica de natureza. E é em sua Terceira Crítica (1790), que esta ruptura se proclama consistentemente, sobretudo devido à retomada de Leibniz (e de suas idéia de natureza e de espaço) e da recuperação da noção platônica de forma.

5. Para Leibniz, as mônadas são o Átomo da Natureza; a substância simples e, por conseguinte, não podem ser dissolvidas (não podem perecer naturalmente) e não podem começar naturalmente (já que elas não poderiam se formar por composição, pois elas são simples), então elas (as mônadas) "[...] só podem começar ou acabar instantaneamente [...] só Ihes é possível começar por criação e acabar por aniquilamento [...]" (LEIBNIZ, 1983, p. 105).

6. Não estamos retirando, dessa obra, influências leibnizianas. Tanto é que, nela, a concepção dinâmica da matéria (herdada de Leibniz) prevalece sobre a concepção cartesiana. Essa concepção dinâmica predomina no conceito de mundo acolhido pelo jovem Kant em detrimento de uma definição matemática adotada por Baumgarten. 0 apoucamento de Leibniz é aqui atribuído quando comparado à larga influência exercida, nela, pelo sistema de Newton.

7. Kant cumpriu a função de Docente Livre, iniciada em 1755, por quatorze anos. Em 1770, com sua Dissertação, ele obteve o posto de professor titular. Mesmo após ter se estabelecido como docente titular da Universidade de Königsberg, ele prosseguiu exercendo o ofício de professor por conta própria até 1793 . Na verdade, ele manteve suas lições públicas até o ano de 1797 . Aos seus cursos privados, ele renunciou em 1793. Kant ofertou - ao longo de sua atividade acadêmica (de $1755 / 56$ a 1796/97) - aproximadamente, 267 ciclos de cursos, sendo que, destes, 54 foram dedicados à lógica e à metafísica; 49 à geografia física; 46 à ética; 28 à antropologia; 24 à física teórica; 20 às matemáticas; 16 ao direito; 12 à enciclopédia das ciências filosóficas; 11 à pedagogia; 04 à mecânica; 02 à mineralogia e 01 à teologia.

8. Entre esses textos, destacamos: O único argumento possível para uma demonstração da existência de Deus (escrito no final de 1762 e publicado em 1763); Investigação sobre a nitidez dos princípios da teologia natural e da moral (concluída em 1762, mas publicada somente 
em 1764); Tentativa de introduzir o conceito de grandezas negativas na filosofia (1763); Sonhos de um visionário esclarecidos pelos sonhos da metafísica (1766).

9. Com relação ao espaço, Kant (1999a), na estética transcendental, assevera: a) o espaço não é um conceito empírico abstraído de experiências externas; b) o espaço é uma representação a priori necessária que subjaz a todas as intuições externas; c) o espaço não é um conceito discursivo, mas uma intuição pura; d) o espaço é essencialmente uno; e) o espaço é representado como uma magnitude infinita dada. Assim, como a forma de todos os fenômenos dos sentidos, o espaço, nessa acepção, nada mais é que a idéia de espaço absoluto de Newton conservada na universalidade da sensibilidade.

10. Logo depois da Crítica da Razão Pura, outros escritos de Kant são publicados: Prolegômenos a toda metafísica futura que possa apresentarse como ciência (1783); Idéia de uma história universal de um ponto de vista cosmopolita (1784); Resposta à pergunta: o que é esclarecimento? (1784); Fundamentação da metafísica dos costumes (1785).

11. Os Princípios Metafísicos de Kant foram publicados exatamente cem anos após os Principia de Newton. O próprio título da obra de Kant já exprime uma diferença fundamental com o escrito newtoniano. Por mais que a matemática seja um constituinte necessário para a ciência da natureza, ela não produz conceitos. Além do mais, os conceitos matemáticos não são conhecimentos por si mesmos, a não ser que se suponha que haja coisas que somente podem ser nos apresentadas segundo a forma desta intuição sensível. Logo, são os princípios e conceitos proporcionados pela metafísica que atuam como substrato das construções matemáticas. Assim, para Kant, a metafísica é o pressuposto da matemática. A ciência da natureza, portanto, necessita de uma metafísica da natureza porque ela deve conter sempre princípios superiores que não sejam empíricos (KANT, 1989).
12. Kant apresenta, em seu Principia, a primeira lei da mecânica: em todos os câmbios da natureza corpórea, a quantidade de matéria permanece a mesma no todo, sem aumento nem diminuição; a segunda lei da mecânica: todo câmbio de matéria tem uma causa externa (todo corpo persevera em seu estado de repouso ou movimento, na mesma direção e com a mesma velocidade, a não ser que uma causa externa o obrigue a abandonar este estado). Esta é a lei da inércia. Na lei da inércia, para Kant, repousaria a possibilidade de uma ciência propriamente dita da natureza; e a terceira lei da mecânica: em toda comunicação de movimento, a ação é sempre igual à reação (KANT, 1989).

13. É evidente que não estamos impugnando ou negando a existência de outros impulsos e estímulos que igualmente conduziram Kant a escrever sua Terceira Crítica. Para um estudo escrupuloso a respeito da problemática que concede razão de ser à Crítica da Faculdade de Julgar, indicamos a sublime obra de Lebrun (1993). 14. Para Kant, o jogo estético se processa paradigmaticamente entre entendimento e imaginação. E Kant parece conceder uma liberdade à imaginação que se mostra movida tão-somente pelo prazer. A experiência estética do sublime será a que mais corresponde ao jogo entre faculdades onde mais claramente se verifica o trabalho em primeiro plano da imaginação. Experimentar o sublime é justamente a vã tentativa de afrontar os limites do entendimento e da sensibilidade. Pois, nesse caso, o objeto estético, por ser "absolutamente grande" não é exprimível em qualquer figura, ele é por definição informe. O sublime é uma grandeza "que só é idêntica a si mesma", para a qual não é possível apresentar um critério de medida e não que há que procurar nas coisas da natureza, mas somente nas nossas idéias. Logo, a estética kantiana não se confina a uma teoria do belo (entendido como o objeto de uma estética do apolíneo e da harmonia entre formas e entre estas e o sujeito). O sublime é o belo "não racionalmente concebível" ou mesmo o "assustador". É assim que o prazer pode ser visto como um desprazer e a experiência não deixa de ser estética e ainda representável. 
15. Entre essas geografias possíveis, Kant destaca: a geografia matemática (trata da forma, da grandeza e do movimento da Terra como das relações desta última com o sistema solar no qual ela se acha); a geografia moral (trata da diversidade dos costumes e dos caracteres humanos relacionados à diversidade das regiões; a geografia política (trata da relação entre o poder político e a constituição do solo como a dos habitantes); a geografia do mercado (trata da relação entre o comércio e a geografia física de uma região); a geografia teológica (trata das formas de religiões no espaço).

\section{Bibliografia}

ABRANTES, Paulo César C. Newton e a Física francesa no século XIX. In: Cadernos de História e Filosofia da Ciência, Campinas, Série 2, v. 1, n. 1 , janeiro a junho de 1989, p. 5-31.

ACZEL, Amir D. O caderno secreto de Descartes. Um mistério que envolve filosofia, matemática, história e ciências ocultas. Rio de Janeiro: Jorge Zahar Editor, 2007.

BASTOS FILHO, Jenner B. \& XAVIER, Roberto Moreira. Conflitos entre os Principia de Newton e os Principia de Descartes. In: Cadernos de História e Filosofia da Ciência, Campinas, Série 2, v. 1, n. 1 , janeiro a junho de 1989, p. 65-76.

BAUAB, Fabrício Pedroso. A reinvenção da geografia no processo de formação da Modernidade: a contribuição de Bernhard Varenio (1621/22-1650). Francisco Beltrão, 2007 (mimeo.).

BERMAN, Marshall. Tudo o que é sólido desmancha no ar: a aventura da modernidade. São Paulo: Companhia das Letras, 1986.

BOROWSKI, Ludwig Ernst. Relato de la vida y el carácter de Immanuel Kant. Madri: Tecnos, 1993.

BURTT, Edwin Arthur. As bases metafísicas da ciência moderna. Brasília: Editora Universidade de Brasília, 1983.

CASINI, Paolo. Newton e a consciência européia. São Paulo: Editora da Universidade Estadual Paulista, 1995.

CHAUÍ, Marilena de Souza. Vida e Obra. In: Leibniz. São Paulo: Abril Cultural, 1983 (Coleção Os Pensadores), p. 93-102.
CLAVIER, Paul. Kant. Les idées cosmologiques. Paris: Presses Universitaires de France, 1997.

COHEN, Bernard e WESTFALL, Richard S (orgs.). Newton: textos, antecedentes, comentários. Rio de Janeiro: Contraponto, EDUERJ, 2002.

COHEN-HALIMI, Michèle. Le Géographe de Königsberg. In: KANT, Immanuel. Géographie. Physische Geographie. Paris: Aubier, 1999, p. 9-40.

CROSBY, Alfred W. A mensuração da realidade. A quantificação e a sociedade ocidental 1250-1600. São Paulo: Editora UNESP, 1999.

DE QUINCEY, Thomas. Os últimos dias de Immanuel Kant. Rio de Janeiro: Forense Universitária, 1989.

DESCARTES, René. Carta-prefácio dos Princípios de Filosofia. São Paulo: Martins Fontes, 2003.

HARVEY, David. Condição pós-moderna. Uma pesquisa sobre as Origens da Mudança Cultural. São Paulo: Edições Loyola, 1996.

HAWKING, Stephen. Os gênios da ciência: sobre os ombros de gigantes. Rio de Janeiro: Elsevier, 2005.

HEGEL, Georg Wilhelm Friedrich. Introdução à História da Filosofia. São Paulo: Rideel, 2005.

HÖFFE, Otfried. Immanuel Kant. São Paulo: Martins Fontes, 2005.

GOMES, Paulo César da Costa. Geografia e Modernidade. Rio de Janeiro: Bertrand Brasil, 2000.

KANT, Immanuel. Principios metafísicos de la 
ciencia de la naturaleza. Madrid: Alianza Editorial, 1989.

KANT, Immanuel. Crítica da Faculdade do Juízo. Lisboa: Imprensa Nacional - Casa da Moeda, 1998.

KANT, Immanuel. Crítica da Razão Pura. São Paulo: Editora Nova Cultural, 1999a.

KANT, Immanuel. Géographie. Physische Geographie. Paris: Aubier, 1999b.

KANT, Immanuel. Forma e princípios do mundo sensível e do mundo inteligível (1770). In: KANT, I. Escritos pré-críticos. São Paulo: Editora UNESP, 2005, p. 219-282.

KOYRÉ, Alexandre. Do mundo fechado ao universo infinito. Rio de Janeiro: Forense Universitária, 2001.

KOYRÉ, Alexandre. O significado da síntese newtoniana. In: COHEN, Bernard e WESTFALL, Richard S (orgs.). Newton: textos, antecedentes, comentários. Rio de Janeiro: Contraponto, EDUERJ, 2002, p. 84-100.

KUBRIN, David. Newton e o cosmo cíclico: a Divina Providência e a filosofia mecânica. In: COHEN, Bernard e WESTFALL, Richard S (orgs.). Newton: textos, antecedentes, comentários. Rio de Janeiro: Contraponto, EDUERJ, 2002, p. 341-359.

LEBRUN, Gerard. Kant e o fim da metafísica. São Paulo: Martins Fontes, 1993.

LEIBNIZ, Gottfried Wilhelm. Os princípios da filosofia ditos a monadologia. In: Leibniz. São Paulo: Abril Cultural, 1983 (Coleção Os Pensadores), p. 103-115.

MANSION, Suzanne. A primeira doutrina da substância. A substância segundo Aristóteles. In: ZINGANO, Marco (org.). Sobre a metafísica de Aristóteles: textos selecionados. São Paulo: Odysseus Editora, 2005, p. 73-92.

MARICONDA, Pablo Rubén. Introdução. O Diálogo e a condenação In: GALILEU, Galilei. Diálogo sobre os dois máximos sistemas do mundo ptolomaico e copernicano. São Paulo: Discurso Editorial, 2000, p. $15-70$.

MARQUES, Antonio. A Terceira Crítica como culminação da filosofia transcendental kantiana. In: KANT, Immanuel. Crítica da Faculdade do Juízo. Lisboa: Imprensa Nacional - Casa da Moeda, 1998.

MERLAN, Philip. Os motores imóveis de Aristóteles. In: ZINGANO, Marco (org.). Sobre a metafísica de Aristóteles: textos selecionados. São Paulo: Odysseus Editora, 2005, p. 27-71.

MOREAU, Denis. Introdução. In: DESCARTES, René. Carta-prefácio dos Princípios de Filosofia. São Paulo: Martins Fontes, 2003, p. XI-XLVIII.

NEWTON, Isaac. Princípios matemáticos da filosofia natural. In: Newton. São Paulo: Abril Cultural, 1983 (Coleção Os Pensadores), p. 1-22.

NEWTON, Isaac. Óptica. In: COHEN, Bernard e WESTFALL, Richard S (orgs.). Newton: textos, antecedentes, comentários. Rio de Janeiro: Contraponto, EDUERJ, 2002, p. 61-81.

ROSS, G. MacDonald. Leibniz. São Paulo: Edições Loyola, 2001.

ROSSI, Paolo. O nascimento da ciência moderna na Europa. Bauru/SP: EDUSC, 2001.

ROSSI, Paolo. A ciência e a filosofia dos modernos: aspectos da Revolução Científica. São Paulo: Editora UNESP, 2002.

SANTIAGO, Homero. Introdução. In: DESCARTES, René. Meditações metafísicas. São Paulo: Martins Fontes, 2005, p. IX-XXXIV.

SCHILLER, Friedrich. "A Educação Estética do Homem. Numa série de cartas". São Paulo: Iluminuras, 1989.

SCHWARTZ, Gilson. Newton e a Economia Política. In: Cadernos de História e Filosofia da Ciência, 
Campinas, Série 2, v. 1, n. 1, janeiro a junho de 1989, p. 53-63.

VERDET, Jean-Pierre. Uma história da astronomia. Rio de Janeiro: Jorge Zahar Editor, 1991.

VITTE, Antonio C. Influências da Filosofia Kantiana na Gênese da Geografia Física, Fortaleza: Revista
Mercator, vol 7, n. 14, 2008, p.57-66.

VITTE, Antonio C. et. all. Considerações sobre os fundamentos artísticos e filosóficos que influenciaram a ciência humboldtiana. Curitiba: VIII Encontro Nacional da ANPEGE, CD-ROM, 2009, p. 1-14. 